\title{
Gender differences relative to smoking behavior and emissions of toxins from mainstream cigarette smoke
}

\author{
Assieh A. Melikian, Mirjana V. Djordjevic, James Hosey, Jie Zhang, \\ Shuquan Chen, Edith Zang, Joshua Muscat, Steven D. Stellman
}

Received 13 July 2005; accepted 9 February 2006

This study examined whether gender differences exist in the exposure to select mainstream cigarette smoke toxins as a result of differences in smoking behavior or type of cigarettes smoked among 129 female and 128 male smokers. Smoking topography data indicated that, compared with men, women took smaller puffs $(37.6 \mathrm{ml} / \mathrm{puff} \mathrm{vs}$. $45.8 \mathrm{ml} /$ puff; $p=.0001)$ of shorter duration (1.33 s/puff vs. $1.48 \mathrm{~s} / \mathrm{puff} ; p=.002)$ but drew more puffs per cigarette (13.5 vs. $12.0 ; p=.001)$ and left longer butts $(36.3 \mathrm{~mm}$ or $40.2 \%$ of cigarette length vs. $34.3 \mathrm{~mm}$ or $39.2 \%$ of cigarette length; $p=.01)$. These trends were similar in both African Americans and European Americans. The emissions of select toxins per cigarette, as determined by mimicking human smoking behaviors were greater among the male smokers than the female smokers and correlated significantly with delivered smoke volume per cigarette. The geometric means of emissions of nicotine from cigarettes were $1.92 \mathrm{mg} /$ cigarette $(95 \% C I=1.80-2.05)$ for women versus $2.20(95 \% C I=2.04-2.37)$ for men $(p=.005)$. Cigarettes smoked by women yielded $139.5 \mathrm{ng} /$ cigarette of 4-(methylnitrosamino)-1-(3-pyridyl)-1-butanone (NNK; 95\% $C I=128.8-151.0$ ), compared with $170.3 \mathrm{ng} /$ cigarette $(95 \% C I=156.3-185.6)$ for men $(p=.0007)$; benzo(a)pyrene $(\mathrm{BaP})$ emissions were $18.0 \mathrm{ng} /$ cigarette $(95 \% C I=17.0-19.0)$ for women and $20.5 \mathrm{ng} /$ cigarette $(95 \% C I=18.8-22.3)$ for men $(p=.01)$. The gender differences with regard to cigarette smoke yields of toxins were more profound in European Americans than in African Americans. On average, African American men's smoking habits produced the highest emissions of select toxins from cigarettes, and European American female smokers had the lowest exposure to carcinogens and toxins. Several studies have suggested that women may be more susceptible than men to the ill effects of carcinogens in tobacco and tobacco smoke, whereas other studies have not found differences in lung cancer risk between men and women. The present study suggests that gender differences in exposure to tobacco smoke cannot account for a higher rate of lung cancer in female smokers compared with male smokers.

\section{Introduction}

Lung cancer currently accounts for $12.7 \%$ of all cancers diagnosed in the United States and for $28.5 \%$ of all cancer deaths (Jamal et al., 2004). According to the 2001 report of the U.S. surgeon general, lung

Assieh A. Melikian, Ph.D., New York University, School of Medicine, Department of Environmental Medicine, Tuxedo, NY; Mirjana V. Djordjevic, Ph.D., National Cancer Institute, Tobacco Control Research Branch, Bethesda, MD; James Hosey, M.S., Jie Zhang, M.S., Shuquan Chen, Ph.D., Edith Zang, Ph.D., Former American Health Foundation Cancer Center, Valhalla, NY; Joshua Muscat, Ph.D., Penn State University, Hershey Medical Center, Hershey, PA; Steven D. Stellman, Ph.D., Department of Epidemiology, Mailman School of Public Health, Columbia University, NY.

Correspondence: Assieh A. Melikian, Ph.D., New York University, School of Medicine, Department of Environmental Medicine, 57 Old Forge Road, Tuxedo, NY 10987, USA. Tel: + 1 (845) 731-3575; Fax: + 1 (845) 351-5472; E-mail: melikian@env.med.nyu.edu cancer has surpassed breast cancer as the foremost cause of cancer deaths among women (U.S. Department of Health and Human Services [USDHHS], 2001). Lung cancer mortality increased sixfold among White women in the United States between 1950 and 1997 (USDHHS, 2001), but lung cancer mortality in women has reached a plateau after many decades of increase (Jamal et al., 2004).

Several studies implied that women who smoke may be more susceptible to lung cancer than are male smokers (Gasperino \& Rom, 2004; Risch et al., 1993; Zang \& Wynder, 1996). Other case-control studies and prospective data, however, have not found differences in lung cancer risk between men and women (Engeland, Andersen, Haldorsen, \& Tretli, 1996; Freund, Belanger, D'Agostino, \& Kannel, 1993; Kreuzer et al., 2000; Marang-van de Mheen, 
Smith, Hart, \& Hole, 2001; Nordlund, Carstensen, \& Pershagen, 1999; Prescott et al., 1998; Simonato et al., 2001; Twombly, 2004). To address this controversy, Bain et al. (2004) analyzed prospective data from former and current smokers in two large cohorts, the Nurses' Health Study of 60,296 women and the Health Professionals follow-up study of 25,397 men. After adjusting for age, number of cigarettes smoked per day, age at onset of smoking, and time since quitting, the researchers found that women do not appear to have a greater susceptibility toward lung cancer than men, given equal exposure to cigarette smoke. However, analyses by histologic type of lung cancer showed that female smokers had a significantly higher rate of adenocarcinoma but a lower risk of large-cell lung cancer, compared with men (Bain et al., 2004; Brownson, Chang, \& Davis, 1992; Khuder, 2001; Koyi, Hillerdal, \& Branden, 2002; Thun et al., 1997). Although Bain et al. (2004) suggest that no gender-based difference exists for risk of lung cancer among smokers, some differences likely exist in the way women and men smoke their cigarettes, in the type of cigarettes they use, and in the way they metabolize smoke carcinogens. Two people may smoke the same brand of cigarette but inhale different doses of carcinogens and toxins due to their specific smoking behavior; thus, they may be exposed to different levels of DNA-damaging agents. If men and women have the same cancer incidence rates and men inhale more carcinogens per cigarette than women, or if differences in metabolism exist, then this analysis may underestimate differences in susceptibility to cancer.

The study we report here compared smoking behavior and emissions of select toxins from cigarettes customarily smoked by men and women. The smoking topography (puff volume, duration, interpuff intervals, and frequency) along with blocking ventilation holes of filter tips and butt length for 129 female and 128 male cigarette smokers was determined using a pressure transducer system. Each smoker's brand and type of cigarette was then machine-smoked under conditions matching the habits of the corresponding participant in the study. The smoke particulates were analyzed for select carcinogens and toxic agents to determine whether the men and women had quantitatively different exposure to cigarette smoke carcinogens.

\section{Method}

\section{Subject recruitment and procedures}

This study was approved by the American Health Foundation's Human Subjects Review Committee. A total of 257 smokers of different types of cigarettes were recruited, through newspaper advertisements in
Westchester County, New York, in 1996-1998 (130 smokers) and 2001-2003 (127 smokers). These volunteers, who were between 18 and 59 years of age, were interviewed by telephone to determine whether they met the following specific inclusion criteria: They had to have smoked at least 10 cigarettes of their current brand daily for at least 1 year, and they had to be in good health, without a history of any tobacco-related disease and without any unstable medical condition. They also had to be free from psychotropic medications and without any psychiatric diagnosis at the time of the study. They were not eligible if they were using smokeless tobacco or other nicotine containing products. Pregnant or nursing women were excluded from the study. Those who were enrolled were informed about all aspects of the study, its goals, and its procedures.

Subjects who met the inclusion criteria were asked to collect cigarette butts for a total of 4 days prior to their visit to the American Health Foundation and to bring the butts to the laboratory. A package including detailed instructions for collection of cigarette butts and plastic bags for storage of butts was mailed to each volunteer. The butts were used to validate the subject's self-reported number of cigarettes smoked per day, to measure the average length of each cigarette smoked, and to evaluate whether blocking of the air vents of filter tips typically occurred during smoking. At the initial visit, each participant was interviewed by a trained interviewer. The Fagerström Test for Nicotine Dependence was used to determine an index of nicotine dependence (Heatherton, Kozlowski, Frecker, \& Fagerström, 1991). Volunteers were also administered American Health Foundation's comprehensive questionnaire to obtain information on smoking history, namely, the age at onset of smoking, quantity of cigarettes and number of years smoked, occupational exposure, family medical history, diet, and other lifestyle factors. During the interview, volunteers disclosed the brand of cigarettes they smoke, including cigarette size, type of pack (hard or soft), and whether they smoked menthol or nonmenthol cigarettes. Detailed cigarette brand information was required to assign the correct Federal Trade Commission (FTC) smoke yield because several varieties with different FTC machine-smoking yields are marketed under the same brand name. All eligible participants signed a written consent statement at enrollment in the study.

\section{Smoking topography measurements}

The volunteers' smoking topography (puff volume, duration, interpuff intervals, and frequency) was measured with a tobacco smoke testing system manufactured at the University of Kentucky 
(Lexington). A detailed description of this puff analyzer was reported previously (Djordjevic, Fan, Ferguson, \& Hoffmann, 1995). This system calculates and stores values for each puff for its volume, duration, interpuff interval, and the total number of puffs per cigarette (Djordjevic et al., 1995; Puustinen, Olkkonen, Kolonen, \& Tuomisto, 1987). Data from all puffs of each cigarette were used to determine the average puff volume, puff duration, and interpuff intervals. The smoking topography of each person was tested twice to ensure the reproducibility of the assay. The time elapsed between two cigarettes smoked was at least a half-hour. Volunteers whose smoking parameters deviated by more than $15 \%$ between the first and second cigarettes were asked to smoke a third cigarette after a one-half-hour or longer time interval. If the smoking parameters for the third cigarette differed significantly from the others, the subject was excluded from the study (five subjects were excluded because of a deviance in topography measurement). Most smoking measurements were carried out between 10:00 A.M. and 1:00 P.M.

The levels of exhaled carbon monoxide (CO) in expired breath were measured with the Vitalograph Breath CO analyzer (Vitalograph Inc., Lenexa, Kansas) immediately after the cigarette was extinguished, and again $10 \mathrm{~min}$ later. This procedure was carried out first when volunteers smoked freely without a testing device in a smoking-designated area in our institute and then again when they used the tobacco smoke testing system adapter in the laboratory setting. The cigarette holder of the puff analyzer does not block the filter vents in the way that smokers do. Thus, degree of filter vent blocking was estimated from the smokers' cigarette butts (see below). Then the filter vents of cigarettes were covered with tape (to simulate each smoker's habit) before topography measurements were taken.

The degree of blocking of filter vents was assessed by observation using the so-called bull's-eye method (Djordjevic, Stellman, \& Zang, 2000; Kozlowski, Pope, \& Lux, 1988), in which the circular pattern of the tar stain is viewed at the end of the filter tip. A completely stained surface indicates complete blocking; a smaller circular stain at the center of the filter tip, surrounded by a white periphery (the bull's eye) indicates no blocking; and incomplete staining of the peripheral circle indicates partial blocking (generally less than $50 \%$ of ventilation holes were blocked).

\section{Measurements of emission of mainstream cigarette smoke toxins}

Chemicals. $\left[{ }^{2} \mathrm{H}_{12}\right]$-benzo(a)pyrene (BaP) was obtained from Cambridge Isotope Laboratories (Andover,
Massachusetts). Tobacco-specific nitrosamines (TSNA) analytical standards, namely $N^{\prime}$-nitrosonornicotine (NNN), 4-(methylnitrosamino)-1-(3-pyridyl)1-butanone (NNK), $N$-nitrosoanatabine (NAT), and $N$-nitrosoanabasine (NAB) were purchased from Toronto Research Chemicals (Ontario, Canada). $\mathrm{N}$ nitrosoguvacoline was synthesized at the American Health Foundation's Organic Synthesis Laboratory.

Machine smoking of cigarettes. For each subject the average smoking parameters were determined from recordings of two cigarettes smoked through the puff analyzer. These parameters were then programmed into a one-channel, piston-type smoking machine (Borgwaldt, Germany; Djordjevic et al., 1995; Djordjevic et al., 2000). Each individual's brand of cigarette was conditioned for $24 \mathrm{hr}$ at room temperature in a $55 \%-65 \%$ relative humidity chamber and then machine-smoked with his or her average smoking parameters, including blocking of the filter tip vents, and specific butt length. For the determination of each analyte the smoke particulates from four cigarettes were collected on 44-mm Cambridge filter pads. To quantify the TSNAs, filter pads were first treated with $2 \mathrm{ml}$ of $2 \%$ ascorbic acid in methanol solution and were air-dried in a chemical fume hood before the collection of smoke particulates.

Determination of $\mathrm{BaP}$ in mainstream smoke emissions. Cigarette smoke condensate (particulate matter) collected from four cigarettes on a Cambridge filter was placed in a $20-\mathrm{ml}$ scintillation vial and $80 \mu \mathrm{l}$ of $1 \mu \mathrm{g} / \mathrm{ml}\left[{ }^{2} \mathrm{H}_{12}\right] \mathrm{BaP}$ in benzene was added as an internal standard, prior to extraction with $3 \times 10 \mathrm{ml}$ $\mathrm{CH}_{2} \mathrm{Cl}_{2}$. After each addition of $\mathrm{CH}_{2} \mathrm{Cl}_{2}$, the vials containing the filters were placed into an ultrasonic bath for $30 \mathrm{~min}$. The three $\mathrm{CH}_{2} \mathrm{Cl}_{2}$ extracts were combined and the solvent was removed under vacuum using a Speedvac. The dry residue was dissolved in $500 \mu \mathrm{l}$ of $\mathrm{CH}_{2} \mathrm{Cl}_{2}$. A $100-\mu 1$ aliquot of extract was applied to a $250-\mathrm{mg}$ Bakerbond column prewashed with $\mathrm{CH}_{2} \mathrm{Cl}_{2}$. This column was eluted with $3 \times 200 \mu \mathrm{l}$ $\mathrm{CH}_{2} \mathrm{Cl}_{2}$. BaP eluates $(2 \mu \mathrm{l})$ from the column were analyzed by gas chromatography-negative chemical ionization-selected ion monitoring-mass spectrometry (GC-NCI-SIM-MS) as described previously (Melikian et al., 1999). The GC-MS analysis was performed on a Hewlett Packard (HP) 5973 mass spectrometer coupled to a HP 6890 gas chromatograph (Wilmington, Delaware) using a ZB-5 $(60 \mathrm{~m} \times 0.25 \mathrm{~mm}$ i.d. $\times 0.25 \mu \mathrm{m}$ film thickness $)$ capillary column (Phenomenex, Torrance, California). The gas chromatograph oven temperature was held at $60^{\circ} \mathrm{C}$ for $3 \mathrm{~min}$, then programmed to rise to $200^{\circ} \mathrm{C}$ at increments of $25^{\circ} \mathrm{C} / \mathrm{min}$, followed by $10^{\circ} \mathrm{C} / \mathrm{min}$ to $310^{\circ} \mathrm{C}$. Under this condition, $\mathrm{BaP}$ is separated from benzo(e)pyrene $(\mathrm{BeP})$, which has a similar molecular 
ion. The mass spectral conditions were as follows: Ion source, $150^{\circ} \mathrm{C}$; emission current, $250 \mu \mathrm{A}$; electron energy, $110 \mathrm{eV}$. The ions monitored were at $\mathrm{m} /$ $z=252$ for $\mathrm{BaP}$ and at $m / z=264$ for the internal standard $\left[{ }^{2} \mathrm{H}_{12}\right] \mathrm{BaP}$.

Determination of tobacco-specific nitrosamines in mainstream smoke emissions. The analysis of TSNA was carried out by a method described previously (Adams, Brunnemann, \& Hoffmann, 1983; Brunnemann \& Hoffmann, 1991). In brief, cigarette smoke particulate matter collected from four cigarettes on a Cambridge filter pretreated with ascorbic acid was extracted with $3 \times 15 \mathrm{ml} \mathrm{CH}_{2} \mathrm{Cl}_{2}$. Pooled $\mathrm{CH}_{2} \mathrm{Cl}_{2}$ extracts were chromatographed on a $15-\mathrm{g}$ basic alumina column (activity II-III; Woelm, Germany). The TSNA fraction was dried and, after the addition of $100 \mu \mathrm{l}$ of $20 \mu \mathrm{g} / \mathrm{ml} N$-nitrosoguvacoline as a chromatographic standard, was analyzed by gas chromatography-thermal energy analysis (GCTEA). The GC-TEA analysis was carried out with an HP Model 5890 gas chromatograph interface with a thermal energy analyzer model 610 (Thermal Energy Corporation, Waltham, Massachusetts). Gas chromatographic analyses were performed on a DB-5 fused silica capillary column $(60 \times 0.32 \mathrm{~mm}, 0.25-\mathrm{m}$ film thickness; Altech, Deerfield, Illinois). The gas chromatograph injection port temperature was $220^{\circ} \mathrm{C}$ and oven temperature was held at $80^{\circ} \mathrm{C}$ for $5 \mathrm{~min}$, then programmed to rise to $140^{\circ} \mathrm{C}$ at increments of $30^{\circ} \mathrm{C} / \mathrm{min}$, then held for $5 \mathrm{~min}$, followed by an increase at $30^{\circ} \mathrm{C} / \mathrm{min}$ to $200^{\circ} \mathrm{C}$ and then held for $15 \mathrm{~min}$. The carrier gas was helium at a flow rate of $3 \mathrm{ml} / \mathrm{min}$.

Determination of nicotine. Nicotine was quantified by a GC method reported previously (Djordjevic et al., 2000).

\section{Data analyses}

Outcome parameters (smoking characteristics, puff profiles, cigarette smoke emissions, and the like) were compared between men and women using $t$-tests and analysis of covariance models to adjust for race and other covariates, such as body mass index. Due to the nonnormal distribution of outcomes, these variables were log-transformed and are presented here as geometric means with 95\% confidence intervals. Tests were considered statistically significant at a $p$ level of less than .05 .

\section{Results}

Comparison of demographic characteristics among female and male smokers

The demographic characteristics of female $(n=129$; $44 \%$ African American) and male $(n=128 ; 43 \%$ African American) smokers who participated in this study are summarized in Table 1 . We found no significant differences regarding age, nicotine dependence, and years smoked between men and women

Table 1. Comparison of smoking characteristic between women and men volunteers.

\begin{tabular}{|c|c|c|c|}
\hline & Women & Men & \\
\hline Variable & Geometric mean $(95 \% \mathrm{Cl})$ & Geometric mean $(95 \% \mathrm{Cl})$ & $p$ value \\
\hline \multicolumn{4}{|l|}{ All subjects } \\
\hline Number of subjects & $n=129$ & $n=128$ & \\
\hline Age (years) & $33.1(31.2-35.0)$ & $35.0(33.3-36.9)$ & .14 \\
\hline Body mass index & $25.5(24.5-26.5)$ & $26.8(26.1-27.4)$ & .06 \\
\hline Cigarettes per day (self-reported) & $15.9(14.7-17.1)$ & $16.8(15.5-18.2)$ & .42 \\
\hline Age at onset of smoking (years) & $15.3(14.7-15.8)$ & $16.4(15.8-17.0)$ & .008 \\
\hline Years smoked & $14.9(13.2-16.9)$ & $15.8(14.0-17.9)$ & .44 \\
\hline Fagerström index & $4.11(3.65-4.62)$ & $4.57(4.12-5.06)$ & .23 \\
\hline \multicolumn{4}{|l|}{ African Americans } \\
\hline Number of subjects & $n=57$ & $n=55$ & \\
\hline Age (years) & $34.4(31.8-37.3)$ & $36.4(34.0-39.1)$ & .29 \\
\hline Body mass index & $27.6(26.0-29.4)$ & $27.3(26.2-28.4)$ & .74 \\
\hline Cigarettes per day (self-reported) & $14.3(12.8-16.0)$ & $14.1(12.8-15.6)$ & .83 \\
\hline Age at onset of smoking (years) & $15.8(14.8-16.8)$ & $16.6(15.8-17.5)$ & .2 \\
\hline Years smoked & $15.7(13.2-18.5)$ & $17.4(14.9-20.4)$ & .37 \\
\hline Fagerström index & $4.12(3.49-4.89)$ & $4.28(3.69-4.93)$ & .78 \\
\hline \multicolumn{4}{|l|}{ European Americans } \\
\hline Number of subjects & $n=72$ & $n=73$ & \\
\hline Age (years) & $32.1(29.6-34.8)$ & $34.1(31.7-36.6)$ & .28 \\
\hline Body mass index & $24.0(22.9-25.1)$ & $26.4(25.6-27.2)$ & .0007 \\
\hline Cigarettes per day (self-reported) & $17.2(15.6-19.0)$ & $19.1(17.1-21.4)$ & .17 \\
\hline Age at onset of smoking (years) & $14.9(14.3-15.5)$ & $16.3(15.5-17.1)$ & .009 \\
\hline Years smoked & $14.3(12.0-17.1)$ & $14.8(12.4-17.6)$ & .81 \\
\hline Fagerström index & $4.09(3.46-4.80)$ & $4.80(4.16-5.52)$ & .15 \\
\hline
\end{tabular}

Note. The $p$ values were calculated using Student's $t$-test. 
within either group, African American or European American. The age at onset of smoking was significantly lower for the European American women than for the European American men (14.9 years vs. 16.3 years; $p=.009$ ), but we found no significant gender difference at onset of smoking among African Americans (15.8 years in women vs. 16.6 years in men; $p=.2$ ). European American women had significantly lower body mass index than did European American men (24.0 vs. 26.4; $p=.0007)$. We found no body mass index difference between African American women versus men (27.6 vs. $27.3 ; p=.74$ ).

Self-reported data for smoking intensity were used for all calculations in this study because the selfreported number of cigarettes smoked per day and counts of cigarette butts collected over 4 days were significantly correlated $(r=.97, n=196, p<.0001)$. In addition, Clark, Gautam, Hlaing, and Gerson (1996) have demonstrated that no significant racial difference exists in the magnitude of error in self-reporting smoking frequency.

\section{Exhaled carbon monoxide}

We found no significant differences in the level of CO exhaled when cigarettes were smoked freely or smoked through the puff analyzer in a laboratory setting (Table 2). We also found no significant racial or gender differences in the level of exhaled CO (Table 2); this finding confirms a previous report that indicates no gender differences in exhaled $\mathrm{CO}$ (Zeman, Hiraki, \& Sellers, 2002). The CO measurement merely indicates that a correlation exists between free smoking and smoking with a cigarette placed in the transducer $(r=.83)$ but does not definitively prove the smoking patterns are similar.
Gender differences in smoking topography and type or brand of cigarettes smoked

Table 3A compares smoking topography among female and male smokers for all subjects; Table 3B describes gender differences in smoking topography among African Americans and European Americans. In general, women took smaller puffs $(M=37.6 \mathrm{ml})$ than men $(M=45.8 \mathrm{ml} ; p=.0001)$. The puff duration also was shorter for women $(M=1.33 \mathrm{~s} /$ puff $)$ than for men $(M=1.48 \mathrm{~s} /$ puff; $p=.002)$. The average number of puffs per cigarette was greater for women $(M=13.5)$ than for men $(M=12.0 ; p=.001)$. These trends were similar in both African American and European American smokers. Average smoke uptake from each cigarette was $507.8 \mathrm{ml}$ for women and $553.0 \mathrm{ml}$ for men (the difference was not statistically significant, $p=.06$ ). Another gender difference in smoking habits was that European American women left significantly longer cigarette butts (mean length $=37.8 \mathrm{~mm}$, or $42.3 \%$ of the length of cigarette), compared with European American men (mean length $=34.6 \mathrm{~mm}$, or $40.0 \%$ of the length of cigarette; $p=.0006$. Among African Americans, the average butt length left by female smokers was $34.5 \mathrm{~mm}$ (37.5\% of the length of cigarette), compared with $33.9 \mathrm{~mm}$ for men $(38.0 \%$ length of the cigarette), $p=.93$.

We found a gender difference in the type of cigarettes smoked by European American smokers, whereas both African American men and women smoked similar cigarettes (Tables 3B and 4B). Among European Americans, women smoked cigarettes with relatively low machine-smoked (FTC) yields of $\mathrm{CO}$, nicotine, and tar. Among African Americans, $87 \%$ of the women and $81 \%$ of the men smoked mentholated cigarettes for which FTC yields of nicotine, $\mathrm{CO}$, and tar were similar.

Table 2. Levels of exhaled carbon monoxide (CO) when cigarettes were smoked in a conventional free environment and when cigarettes were smoked through a puff analyzer in a laboratory setting.

\begin{tabular}{|c|c|c|c|c|c|c|}
\hline & \multicolumn{3}{|c|}{ Women $($ mean $\pm S E)$} & \multicolumn{3}{|c|}{ Men $($ mean $\pm S E)$} \\
\hline & $\begin{array}{l}\text { African } \\
\text { American }\end{array}$ & $\begin{array}{l}\text { European } \\
\text { American }\end{array}$ & $\begin{array}{l}p \text { value } \\
\text { (African } \\
\text { American } \\
\text { European } \\
\text { American) }\end{array}$ & $\begin{array}{l}\text { African } \\
\text { American }\end{array}$ & $\begin{array}{l}\text { European } \\
\text { American }\end{array}$ & $\begin{array}{l}p \text { value } \\
\text { (African } \\
\text { American vs. } \\
\text { European } \\
\text { American) }\end{array}$ \\
\hline Number of subjects & $n=59$ & $n=71$ & & $n=59$ & $n=74$ & \\
\hline $\begin{array}{l}\mathrm{CO}(\mathrm{ppm}) \text { after smoking in } \\
\text { free environment }^{\mathrm{a}}\end{array}$ & $24.63 \pm 1.85^{\star}$ & $21.66 \pm 1.55^{\star \star}$ & .11 & $22.64 \pm 1.85^{\star}$ & $23.12 \pm 1.27^{\star \star}$ & .81 \\
\hline $\begin{array}{l}\mathrm{CO}^{*}(\mathrm{ppm}) \text { after smoking in } \\
\text { laboratory setting }\end{array}$ & $25.38 \pm 1.38^{\star * \star}$ & $22.44 \pm 1.15^{\star \star \star \star}$ & .10 & $22.99 \pm 1.85^{\star \star \star}$ & $23.69 \pm 1.20^{\star \star \star \star}$ & .72 \\
\hline $\begin{array}{l}p \text {-value (CO laboratory } \\
\text { smoking vs. free smoking) }\end{array}$ & .713 & .632 & & .875 & .747 & \\
\hline
\end{tabular}

Note. ${ }^{a}$ Means of exhaled CO immediately and 10 min after smoking cigarette. ${ }^{\mathrm{b}}$ Two-tailed paired $t$-test. ${ }^{\star} p=.36 ;{ }^{\star \star} p=.39 ;{ }^{\star \star \star} p=.24$; $p=.40$. 
Table 3A. Comparison of smoking topography between women and men volunteers.

\begin{tabular}{|c|c|c|c|}
\hline & Women & Men & \\
\hline Variable, all subjects & Geometric mean $(95 \% \mathrm{Cl})$ & Geometric mean $(95 \% \mathrm{Cl})$ & $p$ value \\
\hline Number of subjects & $n=129$ & $n=128$ & \\
\hline Puff volume (ml/puff) & $37.6(35.5-39.9)$ & $45.8(43.2-48.5)$ & .0001 \\
\hline Number of puffs/cigarette & $13.5(12.9-14.1)$ & $12.0(11.4-12.6)$ & .001 \\
\hline Puff duration (s/puff) & $1.33(1.27-1.39)$ & $1.48(1.40-1.56)$ & .002 \\
\hline Puff interval (s/puff) & $20.4(18.9-22.0)$ & $20.7(19.1-22.6)$ & .33 \\
\hline Total puff volume/cigarette (ml) & $507.8(478.3-539.2)$ & $553.0(519.7-588.4)$ & .06 \\
\hline Total puff volume/day (L) & 8.0. (7.34-8.89) & $9.30(8.35-10.4)$ & .02 \\
\hline Length of cigarette smoked $(\mathrm{mm})$ & $54.1(52.7-55.5)$ & $53.2(51.7-54.9)$ & .54 \\
\hline Butt length (mm) & $36.3(35.4-37.2)$ & $34.3(33.4-35.2)$ & .01 \\
\hline Menthol cigarette smokers (percent) & 50 & 50 & \\
\hline Filter tip vents absent or blocked (percent) & 47 & 46 & \\
\hline
\end{tabular}

Note. The $p$ values were calculated using Student's $t$ test.

Comparison of emissions of select mainstream smoke constituents from cigarettes as smoked by women and by men

Table 4A shows the emissions of selected mainstream smoke constituents as generated under each individual's smoking conditions for all subjects in this study. Table 4B compares the differences in emissions of smoke toxins generated by both
African American and European American men and women. Emissions of carcinogens were significantly higher from the cigarettes smoked by European American males than from those smoked by women, whereas these differences were not significant in African Americans, except for NNK per cigarette. In European Americans, the geometric mean of emitted total particulate matter (TPM) from a cigarette was $23.8 \mathrm{mg}$ for women

Table 3B. Comparison of smoking topography between women and men volunteers.

\begin{tabular}{|c|c|c|c|}
\hline & Women & Men & \\
\hline Variable & Geometric mean $(95 \% \mathrm{Cl})$ & Geometric mean $(95 \% \mathrm{Cl})$ & $p$ value \\
\hline \multicolumn{4}{|l|}{ African Americans } \\
\hline Number of subjects & $n=57$ & $n=55$ & \\
\hline Puff volume (ml/puff) & $38.6(35.6-41.8)$ & $47.4(43.5-51.7)$ & .0008 \\
\hline Number of puffs/cigarette & $13.3(12.4-14.4)$ & $11.6(10.6-12.7)$ & .04 \\
\hline Puff duration (s/puff) & $1.31(1.23-1.40)$ & $1.53(1.42-1.64)$ & .003 \\
\hline Puff interval (s/puff) & $20.5(18.3-23.0)$ & $21.5(19.1-24.2)$ & .36 \\
\hline Total puff volume/cigarette (ml) & $515.7(468.9-567.2)$ & $553.4(503.2-608.6)$ & .34 \\
\hline Total puff volume/day (L) & $7.45(6.53-8.49)$ & $7.8(6.75-9.01)$ & .40 \\
\hline Length of cigarette smoked (mm) & $57.3(55.1-59.6)$ & $55.3(52.8-57.9)$ & .29 \\
\hline Butt length $(\mathrm{mm})$ & $34.5(33.4-35.5)$ & $33.9(32.4-35.4)$ & .93 \\
\hline \multirow{5}{*}{$\begin{array}{l}\text { Type of cigarette smoked (mean } \\
\text { FTC nicotine yield/cigarette) }\end{array}$} & $0 \%$ UL & $0 \%$ UL & \\
\hline & $15.5 \% \mathrm{~L}(0.72 \mathrm{mg} / \mathrm{cig})$ & $10.4 \%$ L $(0.78 \mathrm{mg} / \mathrm{cig})$ & \\
\hline & $43.1 \% \mathrm{M}(1.17 \mathrm{mg} / \mathrm{cig})$ & $48.2 \% \mathrm{M}(1.13 \mathrm{mg} / \mathrm{cig})$ & \\
\hline & $41.4 \mathrm{H}(1.4 \mathrm{mg} / \mathrm{cig})$ & $41.4 \% \mathrm{H}(1.4 \mathrm{mg} / \mathrm{cig})$ & \\
\hline & $87 \%$ Menthol (1.2 mg/cig) & $81 \%$ Menthol (1.2 mg/cig) & \\
\hline \multicolumn{4}{|l|}{ European Americans } \\
\hline Number of subjects & $n=72$ & $n=73$ & \\
\hline Puff volume (ml/puff) & $36.9(34.0-40.1)$ & $44.7(41.3-48.3)$ & .001 \\
\hline Number of puffs/cigarette & $13.6(12.8-14.4)$ & $12.3(11.5-13.0)$ & .01 \\
\hline Puff duration (s/puff) & $1.34(1.25-1.44)$ & $1.44(1.33-1.56)$ & .10 \\
\hline Puff interval (s/puff) & $20.2(18.2-22.5)$ & $20.2(17.9-22.7)$ & .62 \\
\hline Total puff volume/cigarette (ml) & $501.7(464.5-541.9)$ & 552.7 (508.9-600.3) & .07 \\
\hline Total puff volume/day (L) & $8.61(7.53-9.85)$ & $10.6(9.1-12.3)$ & .02 \\
\hline Length of cigarette smoked $(\mathrm{mm})$ & $51.7(50.1-53.4)$ & $51.8(49.9-53.9)$ & .84 \\
\hline Butt length (mm) & $37.8(36.5-39.1)$ & $34.6(33.4-35.8)$ & .0006 \\
\hline \multirow{5}{*}{$\begin{array}{l}\text { Type of cigarette smoked } \\
\text { (mean FTC nicotine yield/cigarette) }\end{array}$} & $2.8 \%$ UL $(0.4 \mathrm{mg} / \mathrm{cig})$ & $4.1 \%$ UL $(0.2 \mathrm{mg} / \mathrm{cig})$ & \\
\hline & $57.8 \%$ L $(0.68 \mathrm{mg} / \mathrm{cig})$ & $34.3 \%$ L $(0.74 \mathrm{mg} / \mathrm{cig})$ & \\
\hline & $36.6 \% \mathrm{M}(1.07 \mathrm{mg} / \mathrm{cig})$ & $43.8 \% \mathrm{M}(1.1 \mathrm{mg} / \mathrm{cig})$ & \\
\hline & $2.8 \% \mathrm{H}(1.4 \mathrm{mg} / \mathrm{cig})$ & $17.8 \%$ H $(1.47 \mathrm{mg} / \mathrm{cig})$ & \\
\hline & $21.1 \%$ Menthol $(1.0 \mathrm{mg} / \mathrm{cig})$ & $27.4 \%$ Menthol $(1.1 \mathrm{mg} / \mathrm{cig})$ & \\
\hline
\end{tabular}

Note. $\mathrm{UL}=$ ultra light $(<0.5 \mathrm{mg}$ nicotine $/ \mathrm{cig}) ; \mathrm{L}=$ light $(0.5-0.8 \mathrm{mg}$ nicotine/cig); $\mathrm{M}=$ medium $(0.9-1.2 \mathrm{mg}$ nicotine/cig); $\mathrm{H}=$ high yield $(\geqslant 1.3 \mathrm{mg}$ nicotine/cig). The $p$ values were calculated using Student's $t$ test. 
Table 4A. Comparison of emissions of mainstream smoke toxins from cigarettes smoked by all women and men.

\begin{tabular}{|c|c|c|c|}
\hline & Women & Men & \\
\hline Variable, all subjects & Geometric mean $(95 \% \mathrm{Cl})$ & Geometric mean $(95 \% \mathrm{Cl})$ & $p$ value \\
\hline Number of subjects & $n=127$ & $n=126$ & \\
\hline FTC carbon monoxide/cig (mg) & $12.6(11.9-13.3)$ & $13.6(12.8-14.5)$ & .05 \\
\hline FTC nicotine/cig (mg) & $0.94(0.89-1.00)$ & $1.03(0.96-1.1)$ & .06 \\
\hline FTC tar/cig (mg) & $12.2(11.3-13.1)$ & $13.8(12.7-14.9)$ & .02 \\
\hline HSC nicotine/cig (mg) & $1.92(1.80-2.05)$ & $2.2(2.04-2.37)$ & .005 \\
\hline HSC nicotine/FTC nicotine & 2.04 & 2.14 & \\
\hline HSC TPM/cig (mg) & $29.3(26.9-31.8)$ & $37.0(33.9-40.5)$ & .0001 \\
\hline $\mathrm{HSC}$ BaP/cig (ng) & $18.0(17.0-19.0)$ & $20.5(18.8-22.3)$ & .01 \\
\hline HSC TSNA/cig (ng) & $657.4(608.2-710.5)$ & $770.9(712.8-833.8)$ & .005 \\
\hline HSC NNK/cig (ng) & $139.5(128.8-151.0)$ & $170.3(156.3-185.6)$ & .0007 \\
\hline HSC BaP/day (ng) & $283.8(257.7-312.5)$ & $344.0(306.3-386.3)$ & .02 \\
\hline HSC nicotine/day (mg) & $30.3(27.3-33.6)$ & $37.0(33.2-41.2)$ & .02 \\
\hline HSC NNK/day $(\mu \mathrm{g})$ & $2.2(1.97-2.47)$ & $2.86(2.53-3.24)$ & .004 \\
\hline
\end{tabular}

Note. HSC=human smoking condition; FTC=Federal Trade Commission-specified machine-smoking protocol (35-ml puff volume drawn for $2 s$ once per minute). The $p$ values were adjusted for body mass index using analysis of covariance models.

versus $33.2 \mathrm{mg}$ for men $(p=.0002)$, and the released nicotine per cigarette was $1.63 \mathrm{mg}$ for women versus $2.02 \mathrm{mg}$ for men $(p=.004)$. The BaP yield generated was $16.3 \mathrm{ng} /$ cigarette for women versus $18.9 \mathrm{ng} /$ cigarette for men $(p=.04)$. Finally, NNK emission from cigarettes was $137.1 \mathrm{ng} /$ cigarette for women versus $166.7 \mathrm{ng} /$ cigarette for men $(p=.02$; Table 4B).
Relationships of inhaled cigarette smoke and measured emissions of toxic compounds from cigarettes as smoked by men and women

Figures $1 \mathrm{~A}-\mathrm{D}$ show the relationships of total cigarette smoke intake by mouth and emissions of select toxins as determined in cigarettes smoked by men and women. We observed large interindividual

Table 4B. Emissions of mainstream smoke toxins from cigarettes smoked by African American and European American women and men.

\begin{tabular}{|c|c|c|c|}
\hline & Women & Men & \\
\hline Variable & Geometric mean $(95 \% \mathrm{Cl})$ & Geometric mean $(95 \% \mathrm{Cl})$ & $p$ value \\
\hline \multicolumn{4}{|l|}{ African Americans } \\
\hline Number of subjects & $n=56$ & $n=53$ & \\
\hline FTC carbon monoxide/cig (mg) & $15.4(14.5-16.4)$ & $15.5(14.9-16.2)$ & .85 \\
\hline FTC nicotine/cig (mg) & $1.17(1.10-1.24)$ & $1.17(1.12-1.23)$ & .92 \\
\hline FTC tar/cig (mg) & $15.5(14.4-16.7)$ & $15.9(15.0-16.8)$ & .64 \\
\hline HSC nicotine/cig (mg) & $2.34(2.16-2.55)$ & $2.48(2.24-2.75)$ & .37 \\
\hline HSC nicotine/FTC nicotine & 2.0 & 2.12 & \\
\hline HSC TPM/cig (mg) & $37.6(33.7-41.9)$ & $43.2(38.5-48.5)$ & .08 \\
\hline $\mathrm{HSC}$ BaP/cig (ng) & $20.2(18.8-21.7)$ & $22.8(20.3-25.7)$ & .09 \\
\hline HSC TSNA/cig (ng) & 705.5 (632.4-787.0) & $819.0(736.7-910.6)$ & .05 \\
\hline HSC NNK/cig (ng) & $142.4(126.2-160.7)$ & $175.4(154.6-199.0)$ & .02 \\
\hline HSC BaP/day (ng) & $288.9(252.2-330.9)$ & $320.4(273.6-375.1)$ & .42 \\
\hline HSC nicotine/day (mg) & $33.6(29.2-38.6)$ & $34.8(30.2-40.2)$ & .77 \\
\hline HSC NNK/day $(\mu \mathrm{g})$ & $2.04(1.71-2.43)$ & $2.46(2.09-2.91)$ & .16 \\
\hline \multicolumn{4}{|l|}{ European Americans } \\
\hline Number of subjects & $n=71$ & $n=73$ & \\
\hline FTC carbon monoxide/cig (mg) & $10.7(9.9-11.4)$ & $12.4(11.2-13.6)$ & .03 \\
\hline FTC nicotine/cig (mg) & $0.80(0.74-0.86)$ & $0.93(0.84-1.04)$ & .03 \\
\hline FTC tar/cig (mg) & $10.1(9.2-11.0)$ & $12.4(10.9-14.10)$ & .02 \\
\hline HSC nicotine/cig (mg) & $1.63(1.51-1.76)$ & $2.02(1.83-2.23)$ & .004 \\
\hline HSC nicotine/FTC nicotine & 2.04 & 2.17 & \\
\hline HSC TPM/cig (mg) & $23.8(21.5-26.4)$ & $33.2(29.4-37.5)$ & .0002 \\
\hline $\mathrm{HSC} \mathrm{BaP/cig} \mathrm{(ng)}$ & $16.3(15.1-17.6)$ & $18.9(16.8-21.3)$ & .04 \\
\hline HSC TSNA/cig (ng) & $620.1(556.6-691.0)$ & 736.7 (659.1-823.4) & .04 \\
\hline HSC NNK/cig (ng) & $137.1(123.3-152.5)$ & $166.7(148.3-187.5)$ & .02 \\
\hline HSC BaP/day (ng) & $279.7(244.1-320.5)$ & $361.8(307.1-426.3)$ & .03 \\
\hline HSC nicotine/day (mg) & $27.9(24.0-32.3)$ & $38.6(33.0-45.1)$ & .01 \\
\hline HSC NNK/day ( $\mu \mathrm{g})$ & $2.35(2.02-2.73)$ & $3.19(2.68-3.80)$ & .01 \\
\hline
\end{tabular}

Note. $\mathrm{HSC}=$ human smoking condition; FTC=Federal Trade Commission-specified machine-smoking protocol (35-ml puff volume drawn for $2 \mathrm{~s}$ once per minute). The $p$ values were adjusted for body mass index using analysis of covariance models. 
A: $\quad P=0.005$ (regression slope of $F$ vs $M)$

Female

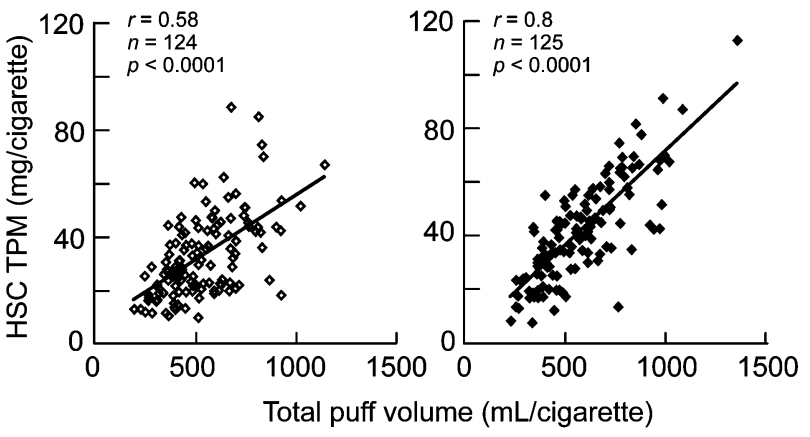

C: $\mathbf{P}=\mathbf{0 . 0 5}$ (regression slope of $\mathrm{F}$ vs $\mathrm{M})$

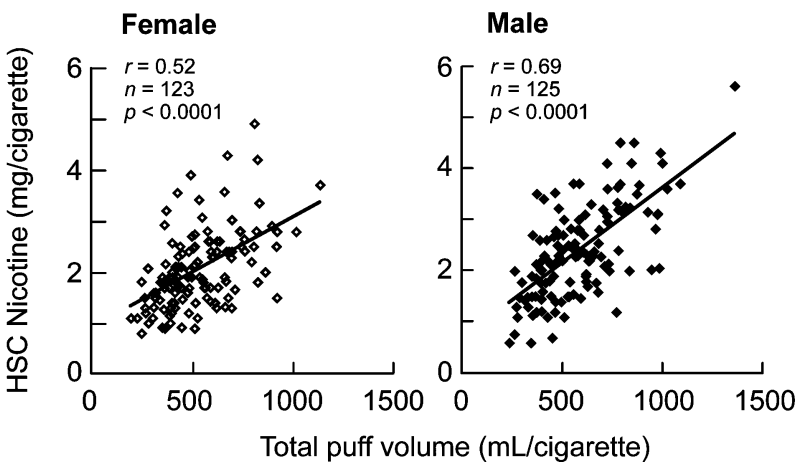

B: $\mathbf{P}=\mathbf{0 . 3 2}$ (regression slope of $F$ vs $M$ )

Female

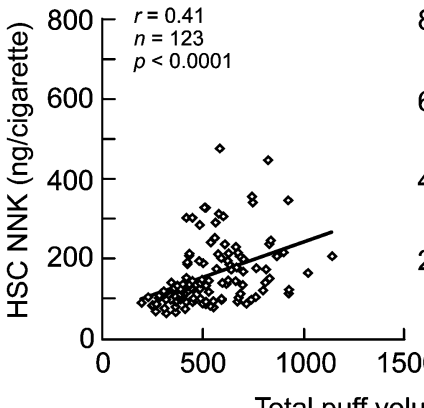

Total puff volume $(\mathrm{mL} /$ cigarette)
Male

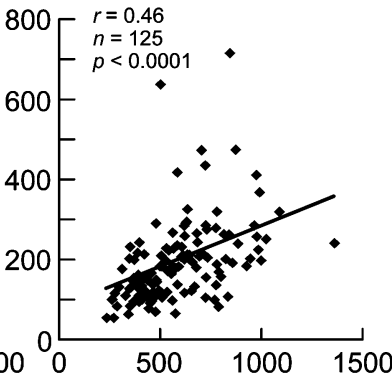

D: $\mathbf{P}<0.0001$ (regression slope of $F$ vs $M$ )

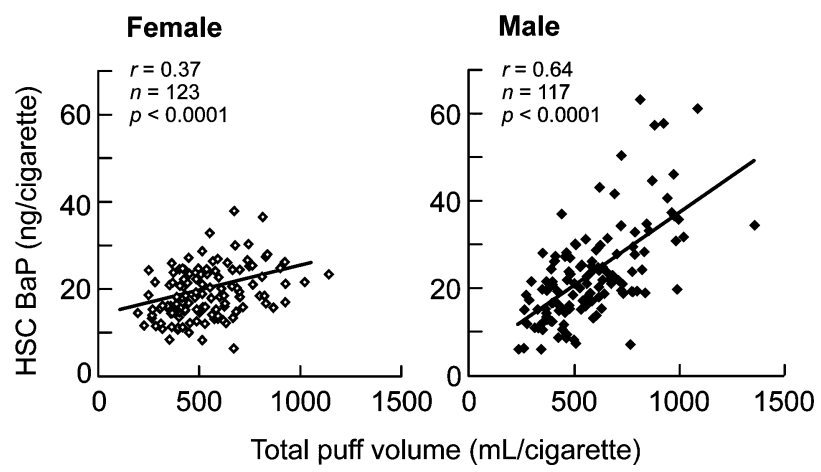

Figure 1. Correlations between total smoke intake per cigarette and emissions of various tobacco smoke toxins: $(A)$ total particulate matter (TPM), $(B)$ NNK, $(C)$ nicotine, and $(D)$ benzo(a)pyrene $(\mathrm{BaP})$ in female and male smokers. HSC, human smoking conditions.

variations in volume of smoke uptake both by women and by men. Total puff volume among women varied from $199 \mathrm{ml}$ to $1,144 \mathrm{ml}$ per cigarette with a median of $514 \mathrm{ml}$; among men, corresponding values ranged from $239 \mathrm{ml}$ to $1,364 \mathrm{ml}$, with a median of $558 \mathrm{ml}$. Similarly, we observed large interindividual variations of emissions of toxins from cigarettes smoked by women and by men primarily due to differences from cigarette to cigarette, and also due to the way they were smoked (e.g., blocking filter vents) and butt length. Variations of emissions of TPM from cigarettes as smoked by women ranged from $9.8 \mathrm{mg}$ to $88.4 \mathrm{mg}$ per cigarette with a median of $28.8 \mathrm{mg} /$ cigarette; when smoked by men, they ranged from $7.1 \mathrm{mg}$ to $112 \mathrm{mg}$ per cigarette with a median of $39.9 \mathrm{mg} /$ cigarette. Corresponding values for nicotine ranged from $0.8 \mathrm{mg}$ to $4.9 \mathrm{mg}$ per cigarette with a median of $1.9 \mathrm{mg} /$ cigarette for women, and from $0.6 \mathrm{mg}$ to $5.6 \mathrm{mg}$ per cigarette for men with a median of $2.3 \mathrm{mg} /$ cigarette. Emissions of NNK per cigarette varied from $61 \mathrm{ng}$ to $445 \mathrm{ng}$ with a median of $126 \mathrm{ng}$ for women, and from $53 \mathrm{ng}$ to $714 \mathrm{ng}$ with a median of $177 \mathrm{ng}$ for men. Corresponding values for $\mathrm{BaP}$ in cigarette smoke ranged from $6.3 \mathrm{ng}$ to $37.8 \mathrm{ng}$ per cigarette with a median of $18.1 \mathrm{ng} /$ cigarette for women, and from $5.9 \mathrm{ng}$ to $63.1 \mathrm{ng}$ per cigarette with a median of $20.9 \mathrm{ng} /$ cigarette for men.
Interindividual variations in emissions of nicotine from a U.S. popular cigarette due to smoking behavior

Figure 2 shows interindividual variations in emissions from a popular U.S. brand of cigarette (nonmentholated, $1.1 \mathrm{mg}$ FTC nicotine/cigarette) when machine-smoked mimicking the smoking parameters of 40 smokers. The emissions of nicotine ranged from $1.1 \mathrm{mg}$ to $4.3 \mathrm{mg}$ per cigarette. On average, human smoking behavior produced about 2.4-fold greater nicotine values than did the machinesmoking with the FTC standard protocol.

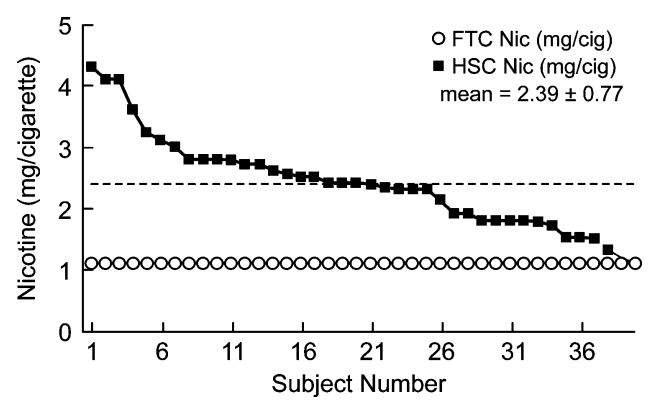

Figure 2. Interindividual variations in uptake of nicotine by smokers who smoke the same popular U.S. brand of cigarette (FTC nicotine $=1.1 \mathrm{mg} /$ cigarette). HSC, human smoking conditions. 


\section{Discussion}

The type or brand of cigarette and the way each cigarette is smoked by an individual affect mainstream smoke yields and, thus, human exposure to harmful compounds. Gender, race, cigarette type, and total number of cigarettes smoked also may affect metabolism of tobacco smoke toxins and, consequently, the exposure to metabolites that are ultimate carcinogens. The study described here examined how differences in smoking behavior (smoking topography) and the type of cigarettes smoked affected the emissions of select toxins from cigarettes smoked by European American and African American women and men. The factors that influence the metabolism of tobacco smoke carcinogens in those smokers are also important and will be presented in a separate paper.

The smoking topography measurements confirmed that puffing patterns of the female smokers differed significantly from those of the male smokers (Eissenberg, Adams, Riggins, \& Likness, 1999). Women took smaller puffs of shorter duration than did men, but they took more puffs per cigarette than the men (Table 3A). European American women left significantly longer cigarette butts than did European American men, but the same finding was not observed among African Americans. By leaving longer cigarette butt lengths, European American women may slightly reduce their exposure to polycyclic aromatic hydrocarbons and nicotine in comparison with other groups, since the smoke yields of TPM, BaP, and nicotine increase with ascending puffs (Melikian \& Djordjevic, 2004).

Cigarettes smoked by women emitted lower amounts of select carcinogens and nicotine than the cigarettes smoked by men (Table 4A), and this difference was more profound among European American smokers. On average, African American men's smoking habits produced the highest emissions of select toxins from cigarettes, and European American female smokers had the lowest exposure to carcinogens and toxins (Table 4B). These differences can be attributed primarily to different types of cigarettes smoked. European Americans, especially women, smoked cigarettes with relatively lower machine-smoked yields (FTC yields) than did African Americans (Table 3A and 3B). European Americans also smoked cigarettes with ventilated filter tips, and most of them did not block the ventilation holes during smoking. African Americans, on the other hand, smoked primarily cigarettes that contained menthol and did not have filter vents.

Studies conducted to date have found that increases in puff volume, decreases in time between puffs, and intentional blocking of filter ventilation each produce significant increases in smoke yields; the latter also alters smoke composition (Borgerding \& Klus, 2005). Gender differences in smoking behavior may affect the smoke yields and composition of carcinogenic agents in cigarette smoke. To assess the influence of an individual's smoking behavior on exposure to cigarette smoke toxins, we compared interindividual variations in emissions (yields) of nicotine from a popular U.S. cigarette as smoked by a small subgroup of 40 smokers (Figure 2). We found a large interindividual variation in nicotine yields, ranging from $1.1 \mathrm{mg}$ to $4.3 \mathrm{mg}$ nicotine per cigarette. On average, the human smoking behavior produced about 2.4-fold greater nicotine values than did the machine-smoking with the FTC standard protocol (35-ml puff volume drawn for $2 \mathrm{~s}$ once per minute). When cigarettes were machine-smoked under the conditions observed in the female and male test groups in the present study, nicotine yields were about 2- to 2.17-fold higher than the emissions recorded when the cigarettes were smoked under the FTC machine-smoking protocol (Tables 4A and 4B). This finding confirms that the FTC protocol underestimates the intake of nicotine and carcinogens by smokers (Djordjevic et al., 2000; Jarvis, Boreham, Primatesta, \& Feyerabend, 2001; Ueda et al. 2002).

Fischer, Spiegelhalder, and Preussmann (1989) have shown that, among the smoking parameters, puff volume and puff frequency have a significant influence on the TSNA yields in mainstream smoke. We found that the emissions of TPM, nicotine, BaP, and NNK also correlate strongly with the total puff volume of smoke generated per cigarette both in male and female smokers (Figure 1). The correlations between smoke per cigarette and emissions of individual toxins were stronger for the cigarettes smoked by men than by women. The slopes of linear regression lines of the plotted emissions of $\mathrm{BaP}$, TPM, and nicotine against total smoke intake were steeper for the cigarettes smoked by men than for those smoked by women. This was especially so for $\mathrm{BaP}$, but no gender difference was seen in exposure to NNK (Figure 1). The significantly higher emissions of $\mathrm{BaP}$ from cigarettes smoked by men could be related partially to the fact that men take larger puffs than women. Taking larger puffs may decrease air velocity in comparison with smaller puffs for the same total volume of smoke, which may provide for less complete combustion and thus somewhat higher polycyclic aromatic hydrocarbons (BaP) formation. In addition, men smoked their cigarettes down to a shorter butt length and used brands that give higher smoke yields when smoked under FTC standard conditions.

Adenocarcinoma of the lung is the histologic type observed more often in women $(62 \%)$ than in men (41\%; Bain et al., 2004; Brownson et al., 1992; 
Khuder, 2001; Koyi et al., 2002; Thun et al., 1997). Cigarette smoke contains several classes of carcinogens, among which polycyclic aromatic hydrocarbons and TSNAs have been studied extensively. A tobacco-specific carcinogen, NNK, is a lung carcinogen in laboratory animals (Hecht, 1998). NNK also was recognized by the International Agency for Research on Cancer as a human carcinogen (Cogliano et al., 2004). When administered to rodents, NNK elicits both adenoma and adenocarcinoma of the lung (Hoffmann \& Hoffmann, 1997). The other major cigarette smoke carcinogens, polycyclic aromatic hydrocarbons such as $\mathrm{BaP}$, induce predominantly squamous cell carcinoma of the lung (Hoffmann \& Hoffmann, 1997; Stellman, Muscat, Thompson, Hoffmann, \& Wynder, 1997). Concentrations of $\mathrm{BaP}$ and NNK in cigarette smoke taken by mouth varied in test subgroups of the present study. Among European Americans, the concentrations of $\mathrm{BaP}$ and NNK were higher in smoke taken in by men than by women; we found no significant gender differences in concentration of select carcinogens in smoke taken in by African Americans. Cigarette smoke taken in by African Americans men had significantly higher concentration of $\mathrm{BaP}(44.5 \mathrm{pg} / \mathrm{ml}$ smoke $)$ than did smoke taken in by European American men $(36.6 \mathrm{pg} / \mathrm{ml}$ smoke), $p=.002$. Similarly, $\mathrm{BaP}$ in smoke taken in was $41.6 \mathrm{pg} / \mathrm{ml}$ smoke for African American women, versus $35.2 \mathrm{pg} / \mathrm{ml}$ smoke for European American women $(p=.014)$. Whether the composition of cigarette smoke constituents plays any role with respect to the observed gender differences in histologic types of lung cancer among smokers remains to be explored further.

In conclusion, the present study shows that emissions (yields) of mainstream smoke carcinogens from cigarettes smoked by women are somewhat lower than those from cigarettes smoked by men. These differences are significant in European Americans. Thus gender differences in exposure to tobacco smoke carcinogens cannot account for a higher risk of lung cancer in women than men. Compared with women, exposure may be underestimated in men using conventional markers such as cigarettes per day or pack-years. The actual dose of carcinogen exposure, gender differences, and the presence of menthol in cigarettes also influence the metabolism of carcinogens, which may affect the development of disease. This topic is not addressed in this paper.

\section{Acknowledgments}

This study was supported by National Cancer Institute grants CA68384, CA17613, and CA70972. The authors thank Julie Heidbrink, Alicia Czander, and Irene Delagado for recruiting smokers; Mohamed Tika for data management; Jingrun Fan and Lisbeth
Eixarch for assistance with the analysis of cigarette smoke emissions; and the Organic Synthesis Laboratory of the American Health Foundation for synthesizing $N$-nitrosoguvacoline.

\section{References}

Adams, J. D., Brunnemann, K. D., \& Hoffmann, D. (1983). Rapid method for the analysis of tobacco-specific N-nitrosamines by gasliquid chromatography with thermal energy analyzer. Journal of Chromatography, 256, 347-351.

Bain, C., Feskanich, D., Speizer, F. E., Thun, M., Hertzmark, E., Rosner, B. A., \& Colditz, G. A. (2004). Lung cancer rates in men and women with comparable histories of smoking. Journal of the National Cancer Institute, 96, 826-834.

Borgerding, M., \& Klus, H. (2005). Analysis of complex mixturescigarette smoke. Experimental Toxicology and Pathology, 57(Suppl. 1), 43-73.

Brownson, R. C., Chang, J. C., \& Davis, J. R. (1992). Gender and histologic type variations in smoking-related risk of lung cancer. Epidemiology, 3, 61-64.

Brunnemann, K. D., \& Hoffmann, D. (1991). Analytical studies on tobacco-specific N-nitrosamines in tobacco and tobacco smoke. Critical Review of Toxicology, 21, 235-240.

Clark, P. I., Gautam, S. P., Hlaing, W. M., \& Gerson, L. W. (1996). Response error in self-reported current smoking frequency by Black and White established smokers. Annals of Epidemiology, 6, 483-489.

Cogliano, V., Straif, K., Bann, R., Grosse, Y., Secretan, B., \& Ghissassi, F. (2004). Smokeless tobacco and related nitrosamines. The Lancet Oncology, 5, 708.

Djordjevic, M. V., Fan, J., Ferguson, S., \& Hoffmann, D. (1995). Selfregulation of smoking intensity. Smoke yields of the low-nicotine, low-'tar' cigarettes. Carcinogenesis, 16, 2015-2021.

Djordjevic, M. V., Stellman, S. D., \& Zang, E. (2000). Doses of nicotine and lung carcinogens delivered to cigarette smokers. Journal of the National Cancer Institute, 92, 106-111.

Eissenberg, T., Adams, C., Riggins, E. C., 3rd., \& Likness, M. (1999) Smokers' sex and the effects of tobacco cigarettes: Subject-rated and physiological measures. Nicotine \& Tobacco Research, 1, 317-324.

Engeland, A., Andersen, A., Haldorsen, T., \& Tretli, S. (1996). The impact of smoking habits on lung cancer risk: 28 years' observation of 26000 Norwegian man and women. Cancer Causes and Control, 7, 366-376.

Fischer, S., Spiegelhalder, B., \& Preussmann, R. (1989). Influence of smoking parameters on the delivery of tobacco-specific nitrosamines in cigarette smoke-A contribution to relative risk evaluation. Carcinogenesis, 10, 1059-1066.

Freund, K. M., Belanger, A. J., D’Agostino, R. B., \& Kannel, W. B (1993). The health risks of smoking. The Framingham Study: 34 years of follow-up. Annals of Epidemiology, 3, 417-424.

Gasperino, J., \& Rom, W. N. (2004). Gender and lung cancer. Clinical Lung Cancer, 5, 353-359. Review.

Heatherton, T. F., Kozlowski, L. T., Frecker, R. C., \& Fagerström, K. O. (1991). The Fagerström Test for Nicotine Dependence: A revision of the Fagerström Tolerance Questionnaire. British Journal of Addiction, 86, 1119-1127.

Hecht, S. S. (1998). Biochemistry, biology, and carcinogenicity of tobacco-specific N-nitrosamines. Chemical Research and Toxicology, 11, 559-603.

Hoffmann, D., \& Hoffmann, I. (1997). The changing cigarette, 19501995. Journal of Toxicology and Environmental Health, 50, 307-364.

Jamal, A., Clegg, L. X., Ward, E., Ries, L. A., Wu, X., Jamison, P. M., Wingo, P. A., Howe, H. L., Anderson, R. N., \& Edwards, B. K. (2004). Annual report to the nation on the status of cancer, 19752001, with a special feature regarding survival. Cancer, 101, 3-27.

Jarvis, M. J., Boreham, R., Primatesta, P., Feyerabend, C., \& Bryant, A. (2001). Nicotine yield from machine-smoked cigarettes and nicotine intakes in smokers: Evidence from representative population survey. Journal of the National Cancer Institute, 93, 134-138.

Khuder, S. A. (2001). Effect of cigarette smoking on major histological types of lung cancer: A meta-analysis. Lung Cancer, 31, 139-148.

Koyi, H., Hillerdal, G., \& Branden, E. (2002). A prospective study of a total material of lung cancer from a county in Sweden 1997-1999: Gender, symptoms, type, stage, and smoking habits. Lung Cancer, $36,9-14$. 
Kozlowski, L. T., Pope, M. A., \& Lux, J. E. (1988). Prevalence of the misuse of ultra-low-tar cigarettes by blocking filter vents. American Journal of Public Health, 78, 694-695.

Kreuzer, M., Boffetta, P., Whitley, E., Ahrens, W., Gaborieau, V., Heinrich, J., Jockel, K. H., Kreienbrock, L., Mallone, S., Merletti, F., Roesch, F., Zambon, P., \& Simonato, L. (2000). Gender differences in lung cancer risk by smoking: A multiple casecontrol study in Germany and Italy. British Journal of Cancer, 82, 227-233.

Marang-van de Mheen, P. J., Smith, G. D., Hart, C. L., \& Hole, D. J. (2001). Are women more sensitive to smoking than men? Findings from the Renfrew and Paisley study. International Journal of Epidemiology, 30, 787-792.

Melikian, A. A., \& Djordjevic, M. V. (2004, September). The role of smoking topography in assessing human smoking and its utility for information machine smoking protocols. $7^{\text {th }}$ Scientific Advisory Study Group on Tobacco Product Regulations (formerly known as SACTob) meeting. Montebello, Canada.

Melikian, A. A., Sun, P., Prokopczyk, B., El-Bayoumy, K., Hoffmann, D., Wang, X., \& Waggoner, S. (1999). Identification of benzo[a]pyrene metabolites in cervical mucus and DNA adducts in cervical tissues in humans by gas chromatography-mass spectrometry. Cancer Letter, 146, 127-134.

Nordlund, L. A., Carstensen, J. M., \& Pershagen, G. (1999). Are male and female smokers at equal risk of smoking-related cancer: Evidence from a Swedish prospective study? Scandinavian Journal of Public Health, 27, 56-62.

Prescott, E., Osler, M., Hein, H. O., Borch-Johnsen, K., Lange, P., Schnohr, P., \& Vestbo, J. (1998). Gender and smoking-related risk of lung cancer. The Copenhagen Center for Prospective Population Studies. Epidemiology, 9, 79-83.

Puustinen, P., Olkkonen, H., Kolonen, S., \& Tuomisto, J. (1987). Microcomputer-aided measurement of puff parameters during smoking of low- and medium-tar cigarettes. Scandinavian Journal of Clinical and Laboratory Investigation, 47, 655-660.
Risch, H. A., Howe, G. R., Jain, M., Burch, J. D., Holowaty, E. J., \& Miller, A. B. (1993). Are female smokers at higher risk for lung cancer than male smokers? A case-control analysis by histologic type. American Journal of Epidemiology, 138, 281-293.

Simonato, L., Agudo, A., Ahrens, W., Benhamou, E., Benhamou, S., Boffetta, P., Brennan, P., Darby, S. C., Forastiere, F., Fortes, C., Gaborieau, V., Gerken, M., Gonzales, C. A., Jockel, K. H., Kreuzer, M., Merletti, F., Nyberg, F., Pershagen, G., Pohlabeln, H., Rosch, F., Whitley, E., Wichmann, H. E., \& Zambon, P. (2001). Lung cancer and cigarette smoking in Europe: An update of risk estimates and assessment of inter-country heterogeneity. International Journal of Cancer, 91, 876-887.

Stellman, S. D., Muscat, J. E., Thompson, S., Hoffmann, D., \& Wynder, E. L. (1997). Risk of squamous cell carcinoma and adenocarcinoma of the lung in relation to lifetime filter cigarette smoking. Cancer, 80, 382-388.

Thun, M. J., Lally, C. A., Flannery, J. T., Calle, E. E., Flanders, W. D., \& Heath, C. W., Jr. (1997). Cigarette smoking and changes in the histopathology of lung cancer. Journal of the National Cancer Institute, 89, 1580-1586.

Twombly, R. (2004). New studies fan controversy over gender risk in lung cancer. Journal of the National Cancer Institute, 96, 898-900.

Ueda, K., Kawachi, I., Nakmura, M., Nogami, H., Shirokawa, N., Masui, S., Okayama, A., \& Oshima, A. (2002). Cigarette nicotine yields and nicotine intake among Japanese male workers. Tobacco Control, 11, 55-60.

U.S. Department of Health and Human Services. (2001). Women and smoking: A report of the surgeon general. Rockville: MD: Author, Public Health Service, Office of the Surgeon General.

Zang, E. A., \& Wynder, E. L. (1996). Differences in lung cancer risk between men and women: Examination of the evidence. Journal of the National Cancer Institute, 88, 83-92.

Zeman, M. V., Hiraki, L., \& Sellers, E. M. (2002). Gender differences in tobacco smoking: Higher relative exposure to smoke than nicotine in women. Journal of Women's Health and Gender-Based Medicine, 11, 147-153. 